\title{
An efficient domino one-pot synthesis of novel spirofuran-indenoquinoxalines by vinyltriphenylphosphonium salts
}

\author{
AFSHIN YAZDANI-ELAH-ABADI ${ }^{\mathrm{a}}$, MALEK-TAHER MAGHSOODLOU ${ }^{\mathrm{a}, *}$, RAZIEH \\ MOHEBAT $^{\mathrm{b}}$ and REZA HEYDARI ${ }^{\mathrm{a}}$ \\ ${ }^{a}$ Department of Chemistry, Faculty of Science, University of Sistan and Baluchestan, P.O. Box: 98135-674, \\ Zahedan, Iran \\ ${ }^{\text {b}}$ Young Researchers and Elite Club, Yazd Branch, Islamic Azad University, Yazd, Iran \\ E-mail: mt_maghsoodlou@yahoo.com
}

MS received 5 March 2017; revised 11 April 2017; accepted 19 April 2017

\begin{abstract}
A simple and convenient multi-component domino reaction has been described for the synthesis of novel spirofuran-indenoquinoxaline derivatives. Products were obtained by a three-component condensation reaction between ninhydrin, aromatic 1,2-diamines and dialkyl ethynedicarboxylates in the presence of a catalytic amount of triphenylphosphine in $\mathrm{CH}_{2} \mathrm{Cl}_{2}$ at ambient temperature in excellent yields. This one-pot process produces biologically and pharmacologically significant heterocycles with the formation of five new bonds (one $\mathrm{C}-\mathrm{C}$, two $\mathrm{C}=\mathrm{N}$ and two $\mathrm{C}-\mathrm{O}$ ) and two new rings in a single operation.
\end{abstract}

Keywords. Multi-component domino reactions (MDRs); one-pot; acetylenic esters; $\mathrm{Ph}_{3} \mathrm{P}$; spirofuranindenoquinoxaline.

\section{Introduction}

Functionalized heterocyclic compounds play considerable roles in the drug discovery process, and analysis of drugs. ${ }^{1,2}$ Among them, heterocyclic systems with nitrogen and oxygen in five- and six-membered rings are of interest due to their pharmaceutical and biological activities. $^{3}$ Therefore, the development of the design and synthesis of new diverse polycyclic heterocycles with potential medicinal and biological activity from readily available starting materials in a cost and time effective manner has received significant attention for research in organic, combinatorial, and medicinal chemistry. ${ }^{4-6}$

In this direction, multi-component reactions (MDRs) involving a domino process, in which more than two components are combined in a single synthetic operation, have been extensively used as a powerful strategy in the synthesis of chemically and biologically important organic frameworks because of their atom-, structure-, bond-forming economy and green chemistry characteristics. $^{7-9}$ These processes can avoid time-consuming and costly processes for purification of various precursors and tedious steps of protection and deprotection of functional groups. ${ }^{10-12}$

\footnotetext{
*For correspondence
}

Spiro heterocycle compounds are found in a number of natural or synthetic molecules. ${ }^{13,14}$ The main construction of many spiro heterocycles show valuable pharmacological and biological properties such as anti-tumor agents, ${ }^{15-17}$ anti-cancer agents, ${ }^{18}$ natural alkaloids, ${ }^{19}$ anti-bacterial and anti-microbial agents, ${ }^{20}$ as an inhibitor growth factor receptor ${ }^{21}$ of particular interest. Spiroheterocycles are also particularly interesting due to the presence of a spirocarbon which provides a strengthening of the structure ${ }^{19,22,23}$ and, together with a diversity of furanes, is the main important core of many pharmacological agents. ${ }^{2,24}$ In this context, spirolactone derivatives have been reported as anti-convulsants and antitumorals. ${ }^{25-27}$

Further, quinoxaline derivatives are an important group of nitrogen-containing heterocycles displaying a broad spectrum of biological activities which have made them privileged structures in pharmacologically active compounds. ${ }^{28,29}$ For example, they show very interesting pharmacological properties such as antibacterial, ${ }^{30}$ antifungal, ${ }^{31}$ antidepressant ${ }^{32}$ and antitumor activities. ${ }^{33}$

As part of our research on the development of new synthetic methods in heterocyclic chemistry and in continuation of our interest in ethyne ester-based MCRs, ${ }^{20,34-39}$ herein, we wish to describe a one-pot, 

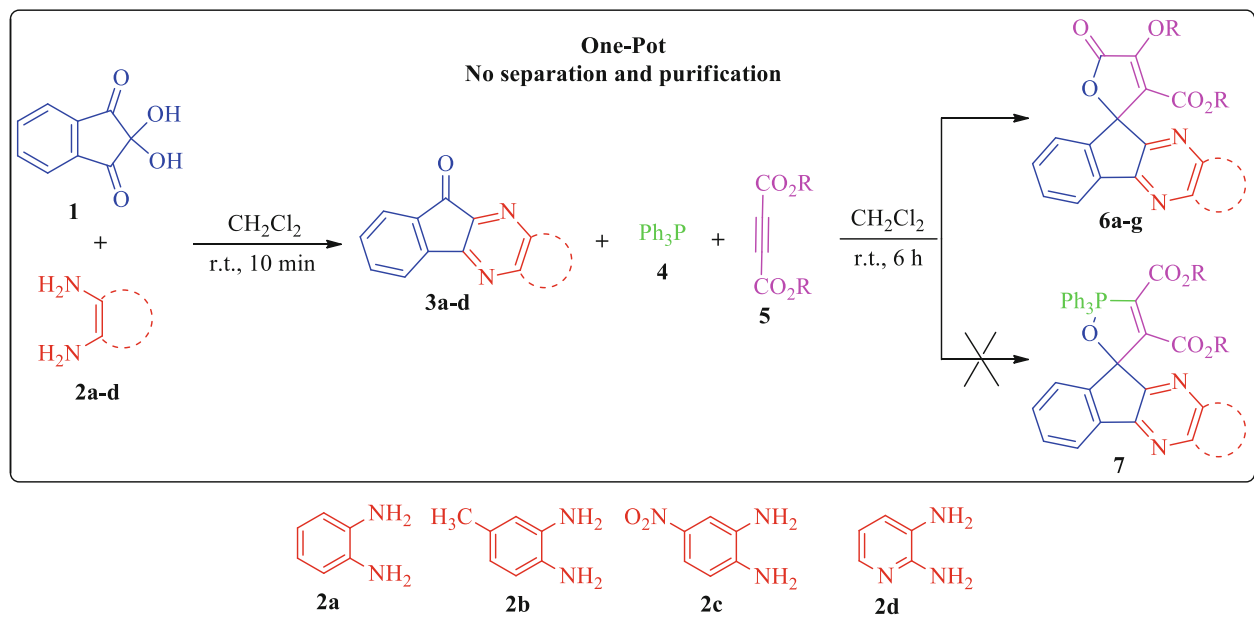

Scheme 1. One-pot, three-component domino synthesis of novel spirofuran-indenoquinoxaline derivatives in the presence of triphenylphosphine as catalyst.

three-component synthesis of novel spirofuranindenoquinoxaline derivatives via the domino reaction of ninhydrin, aromatic 1,2-diamines and dialkyl ethynedicarboxylates in the presence of a catalytic amount of triphenylphosphine in $\mathrm{CH}_{2} \mathrm{Cl}_{2}$ at ambient temperature in excellent yields (Scheme 1).

\section{Experimental}

\subsection{General}

All the reagents and solvents were purchased from Merck and Aldrich and used without further purification. Thin layer chromatography (TLC) was performed on silica gel Polygram SILG/UV 254 plates. All melting points were determined on an Electrothermal 9100 apparatus and are uncorrected. IR spectra were recorded on a Shimadzu IR-470 spectrometer. The ${ }^{1} \mathrm{H}$ NMR and ${ }^{13} \mathrm{C}$ NMR spectra were recorded in $\mathrm{CDCl}_{3}$ on a Bruker DRX-400 or DRX-300 spectrometer operating at 400 or $300 \mathrm{MHz}$ for ${ }^{1} \mathrm{H}$ analysis and 100 or $75 \mathrm{MHz}$ for ${ }^{13} \mathrm{C}$ analysis. Mass spectra were recorded on an Agilent Technology (HP) spectrometer operating at an ionization potential of $70 \mathrm{eV}$. Elemental analyses for $\mathrm{C}, \mathrm{H}$, and $\mathrm{N}$ were performed using a Costech ECS 4010 CHNS-O analyzer in the analytical laboratory of Islamic Azad University Yazd branch.

\subsection{General procedure for the synthesis of novel spirofuran-indenoquinoxaline derivatives $(\boldsymbol{6} \boldsymbol{a}-\mathbf{g})$}

Initially, ninhydrin $\mathbf{1}$ (1 mmol) and aromatic 1,2-diamine $\mathbf{2}$ (1 $\mathrm{mmol}$ ) were added at room temperature to dry $\mathrm{CH}_{2} \mathrm{Cl}_{2}(5 \mathrm{~mL})$ while stirring and in less than 10 min indeno-pyrazine $\mathbf{3}$ was formed. Then, triphenyphosphine $4(5 \mathrm{~mol} \%)$ and a solution of dialkyl ethynedicarboxylate $5(1 \mathrm{mmol})$ in $5 \mathrm{~mL}$ dry $\mathrm{CH}_{2} \mathrm{Cl}_{2}$ were added drop wise to the above reaction mixture which was stirred further at the same conditions for an appropriate time as shown in Table 2. Upon completion of the reaction, monitored by TLC, the solvent was removed under reduced pressure, and the solid residue washed with cold diethyl ether $(2 \times 5 \mathrm{~mL})$ to remove the catalyst and the pure product 6 was obtained as a white powder.

\subsection{The spectral and analytical data of all the compounds}

2.3a Methyl4-methoxy-5-oxo-5H-spiro[furan-2,11'indeno[1,2-b]quinoxaline]-3-carboxylate $(\mathbf{6 a})$ : White powder; yield $0.344 \mathrm{~g}(92 \%)$; M.p. $243-245^{\circ} \mathrm{C}$; IR (KBr): $v_{\max }=3050,2950(\mathrm{CH}$ of aliphatic $), 1779$ and 1699 $(2 \mathrm{C}=\mathrm{O}) \mathrm{cm}^{-1} ;{ }^{1} \mathrm{H}$ NMR $\left(400 \mathrm{MHz}, \mathrm{CDCl}_{3}\right): \delta 3.42(\mathrm{~s}, 3 \mathrm{H}$, $\left.\mathrm{OCH}_{3}\right), 4.51\left(\mathrm{~s}, 3 \mathrm{H}, \mathrm{OCH}_{3}\right), 7.46(\mathrm{~d}, 1 \mathrm{H}, J=7.6 \mathrm{~Hz}, \mathrm{Ar}-$ $\mathrm{H}), 7.57\left(\mathrm{td}, 1 \mathrm{H}, J_{1}=7.6 \mathrm{~Hz}, J_{2}=1.2 \mathrm{~Hz}, \mathrm{Ar}-\mathrm{H}\right), 7.65(\mathrm{td}$, $\left.1 \mathrm{H}, J_{1}=7.6 \mathrm{~Hz}, J_{2}=1.2 \mathrm{~Hz}, \mathrm{Ar}-\mathrm{H}\right), 7.72-7.76(\mathrm{~m}, 1 \mathrm{H}$, Ar-H), 7.78-7.82 (m, 1H, Ar-H), $8.08\left(\mathrm{dd}, 1 \mathrm{H}, J_{1}=8.4 \mathrm{~Hz}\right.$, $\left.J_{2}=1.2 \mathrm{~Hz}, \mathrm{Ar}-\mathrm{H}\right), 8.17\left(\mathrm{dd}, 1 \mathrm{H}, J_{1}=8.4 \mathrm{~Hz}, J_{2}=1.2 \mathrm{~Hz}\right.$, $\mathrm{Ar}-\mathrm{H}), 8.22(\mathrm{~d}, 1 \mathrm{H}, J=7.6 \mathrm{~Hz}, \mathrm{Ar}-\mathrm{H}) \mathrm{ppm} ;{ }^{13} \mathrm{C} \mathrm{NMR}$ $\left(100 \mathrm{MHz}, \mathrm{CDCl}_{3}\right): \delta 52.1$ and $60.4\left(2 \mathrm{OCH}_{3}\right), 84.8\left(\mathrm{C}_{\text {spiro }}\right)$, 120.6, 122.9, 124.1, 129.3, 129.5, 129.7, 130.6, 131.7, 132.1, $138.4,141.5,141.7,143.1,149.6,154.2$ and $156.6\left(16 C_{\text {olefinic }}\right.$ and $\left.\mathrm{C}_{\text {arom }}\right), 160.6$ and $165.8(2 \mathrm{C}=\mathrm{O}) \mathrm{ppm}$; $\mathrm{MS}(\mathrm{m} / z, \%)$ : $374\left(\mathrm{M}^{+}, 100\right), 315$ (96), 272 (69), 228 (30), 114 (8), 59 (21); Anal. Calcd for $\mathrm{C}_{21} \mathrm{H}_{14} \mathrm{~N}_{2} \mathrm{O}_{5}: \mathrm{C}, 67.4 ; \mathrm{H}, 3.8 ; \mathrm{N}, 7.5 \%$. Found: $\mathrm{C}, 67.2 ; \mathrm{H}, 3.7 ; \mathrm{N}, 7.5 \%$.

2.3b Ethyl 4-ethoxy-5-oxo-5H-spiro[furan-2,11'indeno[1,2-b]quinoxaline]-3-carboxylate $(\boldsymbol{6} \boldsymbol{b})$ : White powder; yield $0.362 \mathrm{~g}(90 \%) ;$ M.p. $110-112^{\circ} \mathrm{C}$; IR (KBr): $v_{\max }=3037,2895(\mathrm{CH}$ of aliphatic), 1763 and $1713(2 \mathrm{C}=\mathrm{O})$ $\mathrm{cm}^{-1} ;{ }^{1} \mathrm{H} \mathrm{NMR}\left(300 \mathrm{MHz}, \mathrm{CDCl}_{3}\right): \delta 0.69(\mathrm{t}, 3 \mathrm{H}, J=$ $\left.7.2 \mathrm{~Hz}, \mathrm{OCH}_{2} \mathrm{CH}_{3}\right), 1.55\left(\mathrm{t}, 3 \mathrm{H}, J=6.9 \mathrm{~Hz}, \mathrm{OCH}_{2} \mathrm{CH}_{3}\right)$, 3.66-3.90 (2m, 2H, $\left.\mathrm{OCH}_{2} \mathrm{CH}_{3}\right), 4.83-4.97\left(2 \mathrm{~m}, 2 \mathrm{H}, \mathrm{OCH}_{2}\right.$ $\left.\mathrm{CH}_{3}\right), 7.47(\mathrm{~d}, 1 \mathrm{H}, J=7.5 \mathrm{~Hz}, \mathrm{Ar}-\mathrm{H}), 7.54-7.67(\mathrm{~m}, 2 \mathrm{H}$, Ar-H), 7.70-7.83 (m, 2H, Ar-H), 8.06-8.11 (m, 1H, Ar-H), 
8.14-8.24 (m, 2H, Ar-H) ppm; $\left.{ }^{13} \mathrm{C} \mathrm{NMR} \mathrm{(75} \mathrm{MHz,} \mathrm{CDCl}_{3}\right)$ : $\delta 13.2$ and $15.4\left(2 \mathrm{CH}_{3}\right), 60.9$ and $69.4\left(2 \mathrm{OCH}_{2}\right), 84.9\left(\mathrm{C}_{\text {spiro }}\right)$, $120.8,122.7,124.2,129.3,129.5,129.7,130.5,131.5,132.1$, $138.4,141.4,142.0,142.9,149.4,154.2$ and $156.9\left(16 \mathrm{C}_{\text {olefinic }}\right.$ and $\left.\mathrm{C}_{\text {arom }}\right), 159.9$ and $166.1(2 \mathrm{C}=\mathrm{O}) \operatorname{ppm} ; \mathrm{MS}(\mathrm{m} / \mathrm{z}, \%)$ : $402\left(\mathrm{M}^{+}, 7\right), 273$ (30), 232 (100), 204 (74), 177 (26), 76 (41); Anal. Calcd for $\mathrm{C}_{21} \mathrm{H}_{14} \mathrm{~N}_{2} \mathrm{O}_{5}$ : C, 68.6; H, 4.5; N, 7.0\%. Found: C, 68.3; H, 4.5; N, 7.1\%.

2.3c Methyl 4-methoxy-8'-methyl-5-oxo-5H-spiro [furan-2,11'-indeno[1,2-b]quinoxaline]-3-carboxylate (6c): White powder; yield $0.353 \mathrm{~g}(91 \%)$; M.p. $196-198^{\circ} \mathrm{C}$; IR $(\mathrm{KBr}): v_{\max }=2985,2850$ ( $\mathrm{CH}$ of aliphatic), 1768 and $1694(2 \mathrm{C}=\mathrm{O}) \mathrm{cm}^{-1} ;{ }^{1} \mathrm{H} \mathrm{NMR}\left(400 \mathrm{MHz}, \mathrm{CDCl}_{3}\right): \delta 2.64(\mathrm{~s}$, $\left.3 \mathrm{H}, \mathrm{CH}_{3}\right), 3.42\left(\mathrm{~s}, 3 \mathrm{H}, \mathrm{OCH}_{3}\right), 4.51\left(\mathrm{~s}, 3 \mathrm{H}, \mathrm{OCH}_{3}\right), 7.45-7.47$ (m, 1H, Ar-H), 7.51-7.61 (m, 2H, Ar-H), 7.64-7.66 (m, 1H, Ar-H), 7.99 (d, 1H, $J=8.8 \mathrm{~Hz}, \mathrm{Ar}-\mathrm{H}), 8.03$ (s, 1H, Ar-H), 8.32 (d, $1 \mathrm{H}, J=7.6 \mathrm{~Hz}, \mathrm{Ar}-\mathrm{H}) \mathrm{ppm} ;{ }^{13} \mathrm{C} \mathrm{NMR}(100 \mathrm{MHz}$, $\left.\mathrm{CDCl}_{3}\right): \delta 21.8\left(\mathrm{CH}_{3}\right), 52.0$ and $60.4\left(2 \mathrm{OCH}_{3}\right), 84.9\left(\mathrm{C}_{\text {spiro }}\right)$, 120.6, 122.8, 124.0, 128.5, 128.8, 129.2, 131.6, 131.7, 132.0, $139.9,141.3,141.7,143.1,149.6,154.1$ and $155.6\left(16 C_{\text {olefinic }}\right.$ and $\left.\mathrm{C}_{\text {arom }}\right), 160.6$ and $165.9(2 \mathrm{C}=\mathrm{O}) \mathrm{ppm}$; $\mathrm{MS}(\mathrm{m} / \mathrm{z}, \%)$ : $388\left(\mathrm{M}^{+}, 100\right), 329$ (85), 286 (60), 241 (19), 89 (21), 59 (10); Anal. Calcd for $\mathrm{C}_{22} \mathrm{H}_{16} \mathrm{~N}_{2} \mathrm{O}_{5}$ : C, 68.0; H, 4.1; N, 7.2\%. Found: C, 68.2; H, 4.2; N, 7.1\%.

2.3d Ethyl 4-ethoxy-8'-methyl-5-oxo-5H-spiro[furan2,11'-indeno[1,2-b]quinoxaline]-3-carboxylate (6d): White powder; yield $0.362 \mathrm{~g}(87 \%)$; M.p. $133-135^{\circ} \mathrm{C}$; IR $(\mathrm{KBr}): v_{\max }=3000,2920(\mathrm{CH}$ of aliphatic), 1771 and $1693(2 \mathrm{C}=\mathrm{O}) \mathrm{cm}^{-1} ;{ }^{1} \mathrm{H}$ NMR $\left(400 \mathrm{MHz} \mathrm{CDCl}_{3}\right): \delta$ $0.69\left(\mathrm{t}, 3 \mathrm{H}, J=7.2 \mathrm{~Hz}, \mathrm{OCH}_{2} \mathrm{CH}_{3}\right), 1.56(\mathrm{t}, 3 \mathrm{H}, J=$ $\left.7.2 \mathrm{~Hz}, \mathrm{OCH}_{2} \mathrm{CH}_{3}\right), 2.61\left(\mathrm{~s}, 3 \mathrm{H}, \mathrm{CH}_{3}\right), 3.69-3.86(2 \mathrm{~m}, 2 \mathrm{H}$, $\left.\mathrm{OCH}_{2} \mathrm{CH}_{3}\right), 4.84-4.97\left(2 \mathrm{~m}, 2 \mathrm{H}, \mathrm{OCH}_{2} \mathrm{CH}_{3}\right), 7.45-7.51$ (m, 1H, Ar-H), 7.56-7.62 (m, 1H, Ar-H), 7.64-7.72 (m, 1H, Ar-H), 7.80 (s, 1H, Ar-H), 8.06 (d, 1H, J = 8.4 Hz, Ar$\mathrm{H}), 8.20(\mathrm{~d}, 1 \mathrm{H}, J=7.6 \mathrm{~Hz}, \mathrm{Ar}-\mathrm{H}) \mathrm{ppm} ;{ }^{13} \mathrm{C} \mathrm{NMR}$ $\left(100 \mathrm{MHz} \mathrm{CDCl}_{3}\right): \delta 13.2,15.5$ and $21.7\left(3 \mathrm{CH}_{3}\right), 60.9$ and $69.4\left(2 \mathrm{OCH}_{2}\right), 85.0\left(\mathrm{C}_{\text {spiro }}\right), 120.9,122.5,124.1,128.4$, $128.5,131.9,132.0,132.1,132.2,138.6,140.1,141.3,141.8$, 149.4, 153.5, and 156.8 ( $16 \mathrm{C}_{\text {olefinic }}$ and $\left.\mathrm{C}_{\text {arom }}\right), 159.9$ and $166.2(2 \mathrm{C}=\mathrm{O}) \operatorname{ppm} ; \mathrm{MS}(\mathrm{m} / \mathrm{z}, \%): 416\left(\mathrm{M}^{+}, 11\right), 343(3)$, 277 (100), 201 (18), 183 (21), 77 (25); Anal. Calcd for $\mathrm{C}_{24} \mathrm{H}_{20} \mathrm{~N}_{2} \mathrm{O}_{5}$ : C, 69.2; H, 4.8; N, 6.7\%. Found: C, 69.3; H, $4.9 ; \mathrm{N}, 6.9 \%$.

2.3e Methyl4-methoxy-7'-nitro-5-oxo-5H-spiro[furan -2,11'-indeno[1,2-b]quinoxaline]-3-carboxylate (6e): White powder; yield 0.381 g (91\%); M.p. 247-249 ${ }^{\circ}$; IR $(\mathrm{KBr}): v_{\max }=3050,2920$ (CH of aliphatic), 1760 and $1694(2 \mathrm{C}=\mathrm{O}) \mathrm{cm}^{-1} ;{ }^{1} \mathrm{H} \mathrm{NMR}\left(400 \mathrm{MHz}, \mathrm{CDCl}_{3}\right): \delta 3.49(\mathrm{~s}$, $\left.3 \mathrm{H}, \mathrm{OCH}_{3}\right), 4.53\left(\mathrm{~s}, 3 \mathrm{H}, \mathrm{OCH}_{3}\right), 7.51-7.53(\mathrm{~m}, 1 \mathrm{H}, \mathrm{Ar}-\mathrm{H})$, 7.65-7.74 (m, 2H, Ar-H), 8.26-8.31 (m, 2H, Ar-H), 8.58 (dd, $\left.1 \mathrm{H}, J_{1}=9.2 \mathrm{~Hz}, J_{2}=2.4 \mathrm{~Hz}, \mathrm{Ar}-\mathrm{H}\right), 8.99-9.00(\mathrm{~m}, 1 \mathrm{H}$, Ar-H) ppm; ${ }^{13} \mathrm{C}$ NMR $\left(100 \mathrm{MHz}, \mathrm{CDCl}_{3}\right): \delta 52.3$ and 60.5 $\left(2 \mathrm{OCH}_{3}\right), 84.3\left(\mathrm{C}_{\text {spiro }}\right), 120.2,124.4,125.9,128.5,130.7$, $132.0,132.2$, 133.5, 137.5, 140.4, 142.4, 146.1, 147.3, 149.6,
157.0 and $159.4\left(16 \mathrm{C}_{\text {olefinic }}\right.$ and $\left.\mathrm{C}_{\text {arom }}\right), 160.6$ and 165.4 $(2 \mathrm{C}=\mathrm{O}) \mathrm{ppm} ; \mathrm{MS}(\mathrm{m} / \mathrm{z}, \%): 419\left(\mathrm{M}^{+}, 49\right), 360(55), 317$ (29), 215 (13), 84 (53), 49 (100); Anal. Calcd for $\mathrm{C}_{21} \mathrm{H}_{13} \mathrm{~N}_{3} \mathrm{O}_{7}$ : C, 60.1 ; H, 3.1; N, 10.0\%. Found: C, 59.9; H, 3.0; N, 9.9\%.

\section{3f Ethyl4-ethoxy-7'-nitro-5-oxo-5H-spiro[furan} -2,11'-indeno[1,2-b]quinoxaline]-3-carboxylate (6f): White powder; yield $0.380 \mathrm{~g}(85 \%)$; M.p. $175-177^{\circ} \mathrm{C}$; IR $(\mathrm{KBr}): v_{\max }=3040,2900$ (CH of aliphatic), 1763 and $1715(2 \mathrm{C}=\mathrm{O}) \mathrm{cm}^{-1} ;{ }^{1} \mathrm{H}$ NMR $\left(400 \mathrm{MHz}, \mathrm{CDCl}_{3}\right): \delta 0.79$ $\left(\mathrm{t}, 3 \mathrm{H}, J=7.2 \mathrm{~Hz}, \mathrm{OCH}_{2} \mathrm{CH}_{3}\right), 1.58(\mathrm{t}, 3 \mathrm{H}, J=6.9 \mathrm{~Hz}$, $\left.\mathrm{OCH}_{2} \mathrm{CH}_{3}\right), 3.76-3.92\left(2 \mathrm{~m}, 2 \mathrm{H}, \mathrm{OCH}_{2} \mathrm{CH}_{3}\right), 4.86-5.00(2 \mathrm{~m}$, $\left.2 \mathrm{H}, \mathrm{OCH}_{2} \mathrm{CH}_{3}\right), 7.52-7.54(\mathrm{~m}, 1 \mathrm{H}, \mathrm{Ar}-\mathrm{H}), 7.65-7.76(\mathrm{~m}, 2 \mathrm{H}$, Ar-H), 8.25-8.33 (m, 2H, Ar-H), 8.56-8.61 (m, 1H, Ar-H), 8.98-9.00 (m, 1H, Ar-H) ppm; $\left.{ }^{13} \mathrm{C} \mathrm{NMR} \mathrm{(100} \mathrm{MHz,} \mathrm{CDCl}_{3}\right)$ : $\delta 13.3$ and $15.5\left(2 \mathrm{CH}_{3}\right), 61.2$ and $69.6\left(2 \mathrm{OCH}_{2}\right), 84.3\left(\mathrm{C}_{\text {spiro }}\right)$, $120.3,123.6,124.1,124.5,125.9,128.4,130.6,132.0,133.5$, $137.5,140.3,142.6,147.3,149.4,155.2$ and $157.0\left(16 C_{\text {olefinic }}\right.$ and $\left.\mathrm{C}_{\text {arom }}\right), 159.7$ and $165.7(2 \mathrm{C}=\mathrm{O}) \operatorname{ppm}$; $\mathrm{MS}(\mathrm{m} / \mathrm{z}, \%)$ : $447\left(\mathrm{M}^{+}, 30\right), 403$ (27), 318 (100), 277 (38), 201 (21), 75 (16); Anal. Calcd for $\mathrm{C}_{23} \mathrm{H}_{17} \mathrm{~N}_{3} \mathrm{O}_{7}$ : C, 61.7; H, 3.8; N, 9.3\%. Found: C, 61.6; H, 3.7; N, 9.4\%.

\section{3g Methyl4-methoxy-5-oxo-5H-spiro[furan-2,6'} -indeno[1,2-b]pyrido[3,2-e]pyrazine]-3-carboxylate $(6 g)$ : White powder; yield $0.319 \mathrm{~g}(85 \%)$; M.p. $125-128^{\circ} \mathrm{C}$; IR $(\mathrm{KBr}): v_{\max }=3050,2950(\mathrm{CH}$ of aliphatic), 1779 and $1700(2 \mathrm{C}=\mathrm{O}) \mathrm{cm}^{-1} ;{ }^{1} \mathrm{H} \mathrm{NMR}\left(400 \mathrm{MHz}, \mathrm{CDCl}_{3}\right): \delta 3.41(\mathrm{~s}$, $\left.3 \mathrm{H}, \mathrm{OCH}_{3}\right), 4.50\left(\mathrm{~s}, 3 \mathrm{H}, \mathrm{OCH}_{3}\right), 7.29-7.30(\mathrm{~m}, 1 \mathrm{H}, \mathrm{Ar}-\mathrm{H})$, 7.45-7.50 (m, 1H, Ar-H), 7.54-7.58 (m, 1H, Ar-H), 7.66$7.71(\mathrm{~m}, 1 \mathrm{H}, \mathrm{Ar}-\mathrm{H}), 8.34(\mathrm{~d}, 1 \mathrm{H}, J=7.6 \mathrm{~Hz}, \mathrm{Ar}-\mathrm{H}), 8.43$ $\left(\mathrm{dd}, 1 \mathrm{H}, J_{1}=8.4 \mathrm{~Hz}, J_{2}=2.0 \mathrm{~Hz}, \mathrm{Ar}-\mathrm{H}\right), 9.14-9.16(\mathrm{~m}, 1 \mathrm{H}$, Ar-H) ppm; ${ }^{13} \mathrm{C}$ NMR $\left(100 \mathrm{MHz}, \mathrm{CDCl}_{3}\right): \delta 52.2$ and 60.5 $\left(2 \mathrm{OCH}_{3}\right), 84.7\left(\mathrm{C}_{\text {spiro }}\right), 123.2,124.0,124.6,128.4,128.5$, 131.9, 132.0, 132.1, 132.2, 138.3, 138.6, 142.3, 149.7, 153.9, and $157.5\left(16 \mathrm{C}_{\text {olefinic }}\right.$ and $\left.\mathrm{C}_{\text {arom }}\right), 160.4$ and $165.6(2 \mathrm{C}=\mathrm{O})$ ppm; MS (m/z,\%): $375\left(\mathrm{M}^{+}, 7\right), 277$ (100), 201 (16), 183 (28), 77 (23), 51 (19); Anal. Calcd for $\mathrm{C}_{20} \mathrm{H}_{13} \mathrm{~N}_{3} \mathrm{O}_{5}$ : C, 64.0; H, 3.5; N, 11.2\%. Found: C, 64.0; H, 3.6; N, 11.0\%.

\section{Results and Discussion}

On the basis of the well-established chemistry of trivalent phosphorus nucleophiles, ${ }^{40-43}$ it is reasonable to assume that spiro-1,2-oxaphospholes 7 results from the initial addition of triphenyphosphine 4 (1 mmol) to the acetylenic ester $\mathbf{5}(1 \mathrm{mmol})$ and subsequent attack of the resulting anion to the carbonyl carbon of the aromatic ketone ${ }^{44} \mathbf{3}$ (1 mmol), which apparently cyclizes, in $\mathrm{CH}_{2} \mathrm{Cl}_{2}$ at room temperature, to deliver the spiro-1,2-oxaphospholes 7. In the event we did not observe the expected MCR product 7; instead, the reaction afforded the corresponding methyl 4-methoxy-5oxo-5 $\mathrm{H}$-spiro[furan-2,11'-indeno[1,2- $b$ ] quinoxaline]3 -carboxylate $\mathbf{6 a}$ with triphenylphosphine playing as 


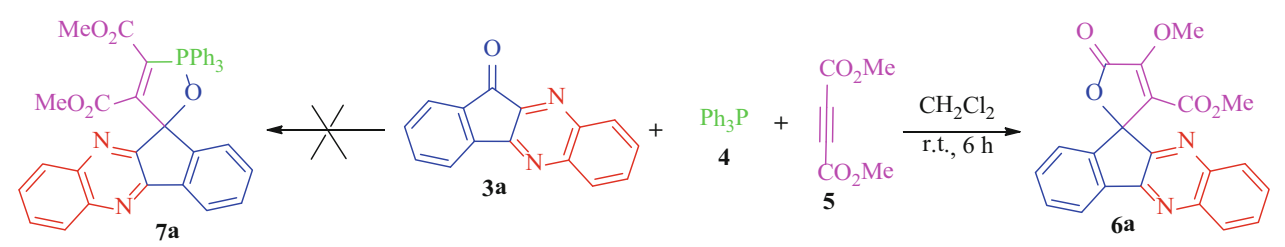

Scheme 2. Synthesis of novel spirofuran-indenoquinoxaline derivatives.

Table 1. Optimization of reaction conditions of compound $\mathbf{6} \mathbf{a}^{\mathrm{a}}$.

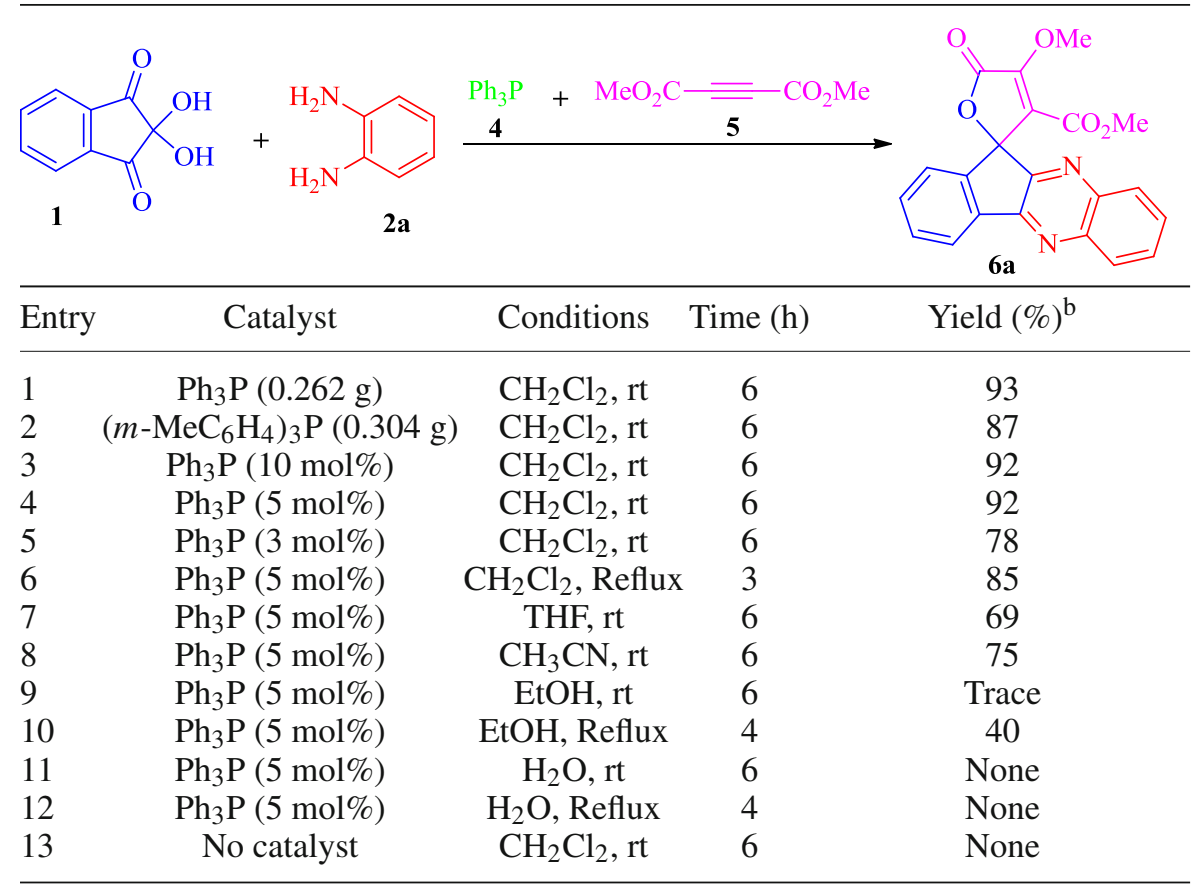

a Reaction conditions: ninhydrine ( $1 \mathrm{mmol})$, benzene-1,2-diamine (1 mmol), DMAD (1 mmol) and solvent $(10 \mathrm{~mL})$; rt.

${ }^{\mathrm{b}}$ Isolated yields.

a catalyst ${ }^{45-47}$ in the reaction between the dimethyl acetylenedicarboxylate and $11 \mathrm{H}$-indeno[1,2- $b$ ] quinoxalin-11-one 3a (Scheme 2).

In order to minimize the steps required for the formation of the product and to simplify the process, a one-pot, three-component domino protocol was planned, understanding the necessity to separate intermediate $\mathbf{3}$ as well as the control of reaction time (Scheme 1). We began this study by subjecting ninhydrine $(1 \mathrm{mmol})$, benzene1,2-diamine (1 mmol) and triphenyphosphine (1 mmol) to the reactions with dimethyl ethynedicarboxylate (1 mmol) in $\mathrm{CH}_{2} \mathrm{Cl}_{2}$ at room temperature. Unfortunately, complex mixtures were observed. To minimize the formation of byproducts, the ninhydrine and benzene-1,2diamine were mixed at rt until, in less than 10 minutes, $11 \mathrm{H}$-indeno[1,2- $b$ ]quinoxalin-11-one 3a was formed without use of any catalyst or activator. Next, triphenyphosphine and dimethyl ethynedicarboxylate were added and the mixture was stirred further at the same conditions for $6 \mathrm{~h}$. The desired product $\mathbf{6 a}$ was obtained as a white solid in $93 \%$ yield with triphenylphosphine playing as a catalyst. This two-step procedure allows the one-pot three-component reaction to be controlled, avoiding the separation of intermediates, as well as the time-consuming and costly purification processes.

We investigated another derivative of phosphine as catalyst on the model reaction. As shown in Table 1, the reactions were efficiently promoted in the presence of triphenylphosphine with increased yields rather than tri- $m$-tolylphosphine. Also, the effect of the amount of catalyst on the conversion and rate of the reaction was evaluated by varying the amount of $\mathrm{Ph}_{3} \mathrm{P}$ in $\mathrm{CH}_{2} \mathrm{Cl}_{2}$ at $\mathrm{rt}$ (Table 1, entries 1,3-5). The best results were obtained in the presence of $5 \mathrm{~mol} \%$ of $\mathrm{Ph}_{3} \mathrm{P}$ (Table 1, entry 4).

To find the optimized reaction conditions, the synthesis of compound $\mathbf{6 a}$ was examined in various aprotic and protic solvents at reflux and room temperature conditions. As Table 1 indicates, the best results were obtained 
Table 2. Domino one-pot three-component synthesis of spirofuranindenoquinoxaline derivatives ${ }^{\mathrm{a}}$.

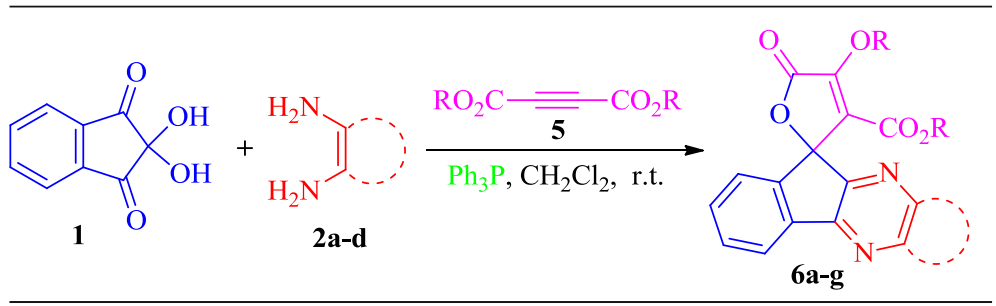

\begin{tabular}{lccccc}
\hline \multicolumn{3}{l}{ Entry Diamine } & $\mathrm{R}$ & Product Time (h) & Yield $(\%)^{\mathrm{b}}$ \\
\hline 1 & $\mathbf{2 a}$ & $\mathrm{Me}$ & $\mathbf{6 a}$ & 6 & 92 \\
2 & $\mathbf{2 a}$ & $\mathrm{Et}$ & $\mathbf{6 b}$ & 6 & 90 \\
3 & $\mathbf{2 b}$ & $\mathrm{Me}$ & $\mathbf{6 c}$ & 8 & 91 \\
4 & $\mathbf{2 b}$ & $\mathrm{Et}$ & $\mathbf{6 d}$ & 8 & 87 \\
5 & $\mathbf{2 c}$ & $\mathrm{Me}$ & $\mathbf{6 e}$ & 8 & 91 \\
6 & $\mathbf{2 c}$ & $\mathrm{Et}$ & $\mathbf{6 f}$ & 8 & 85 \\
7 & $\mathbf{2 d}$ & $\mathrm{Me}$ & $\mathbf{6 g}$ & 8 & 85 \\
\hline
\end{tabular}

${ }^{a}$ Reaction conditions: ninhydrin $(1 \mathrm{mmol})$, aromatic 1,2 -diamine (1 mmol), dialkyl ethynedicarboxylate (1 mmol), $\mathrm{Ph}_{3} \mathrm{P}(5 \mathrm{~mol} \%), \mathrm{CH}_{2} \mathrm{Cl}_{2}$ $(10 \mathrm{~mL})$; rt.

${ }^{\mathrm{b}}$ Isolated yields.

in dry $\mathrm{CH}_{2} \mathrm{Cl}_{2}$ at $\mathrm{rt}$ with excellent yield (Table 1, entry 4) and also, other aprotic solvents showed much better performance relative to protic solvents. The desired product 6a was not obtained when the reaction was carried out in $\mathrm{CH}_{2} \mathrm{Cl}_{2}$ under catalyst-free conditions at $\mathrm{rt}$ for $6 \mathrm{~h}$ (Table 1, entry 13).

After extensive screening, we found that the optimized best yields and time profiles were obtained with 5 mol\% of $\mathrm{Ph}_{3} \mathrm{P}$ in $\mathrm{CH}_{2} \mathrm{Cl}_{2}$ at ambient temperature, which furnished the corresponding methyl 4-methoxy-5-oxo$5 H$-spiro[furan-2,11'-indeno[1,2- $b$ ] quinoxaline]-3 -carboxylate 6a in $92 \%$ yield within $6 \mathrm{~h}$ (Table 1, entry 4).

Using these optimized conditions, we turned our attention to investigate the scope and general applicability of this methodology by carrying out the synthesis of spirofuran-indenoquinoxaline derivatives using different aromatic 1,2-diamines and electron-deficient ethynic esters (Table 2).

All the reactions were completed in 6-8 $\mathrm{h}$ and resulted in the formation of the target structures (Table 2, entries 1-7) in high yields and this domino reaction was efficiently promoted using benzene-1,2-diamine and dimethyl acetylenedicarboxylate with reduced reaction times and increased yields compared to other reactants.

The isolated products $\mathbf{6 a}-\mathbf{g}$ were characterized on the basis of IR, ${ }^{1} \mathrm{H},{ }^{13} \mathrm{C}$ NMR and MS spectroscopy and elemental analysis. The mass spectra of these compounds displayed molecular ion peaks at the appropriate $m / z$ values at $374,402,388,416,419,447$ and 375 , respectively. The ${ }^{1} \mathrm{H}$ NMR spectrum of $\mathbf{6 a}$ exhibited two single sharp lines at $\delta 3.42$ and $4.51 \mathrm{ppm}$, characteristic for the two methyl protons of the esters. The other aromatic protons resonate as two doublets, two triplet of doublets, two multiplets and two doublet of doublets at the range $\delta 7.45-8.23 \mathrm{ppm}$. The ${ }^{13} \mathrm{C}$ NMR spectrum of $\mathbf{6 a}$ showed twenty-one distinct resonances in agreement with the proposed structure (see Experimental section). The characteristic signal due to the spiro carbon is described at $\delta 84.8$ and the carbons of the $\mathrm{C}=\mathrm{O}$ groups resonated at $\delta 160.6$ and $165.8 \mathrm{ppm}$. The structural assignments made on the basis of the NMR spectra of compound $\mathbf{6 a}$ are supported by its IR spectrum. The $\mathrm{CH}$ of aliphatic and ester groups exhibited strong absorption bands at 3050, 2950, 1779 and $1699 \mathrm{~cm}^{-1}$. Similarly, compounds $6 \mathbf{b}-\mathbf{g}$ were characterized (Table 2).

In order to determine the catalytic behaviour of triphenyphosphine, the suggested mechanism for the formation of the products is shown in Scheme 3. On the basis of this mechanism, initially, indeno-pyrazine $\mathbf{3}$ is produced from the addition of ninhydrin $\mathbf{1}$ to aromatic 1,2-diamine 2 . On the other hand, 1,3-dipolar intermediate 8 is formed by the 1:1 interaction between the $\mathrm{Ph}_{3} \mathrm{P}$ and ethynic compound $\mathbf{5}$, which attacks preferentially the carbonyl group of indeno-pyrazine 3, leading to dipolar intermediate 9. Cyclization of this zwitterionic intermediate leads to intermediate $\mathbf{1 0}$ and its subsequent conversion to the spirocyclic product $\mathbf{6}$. 


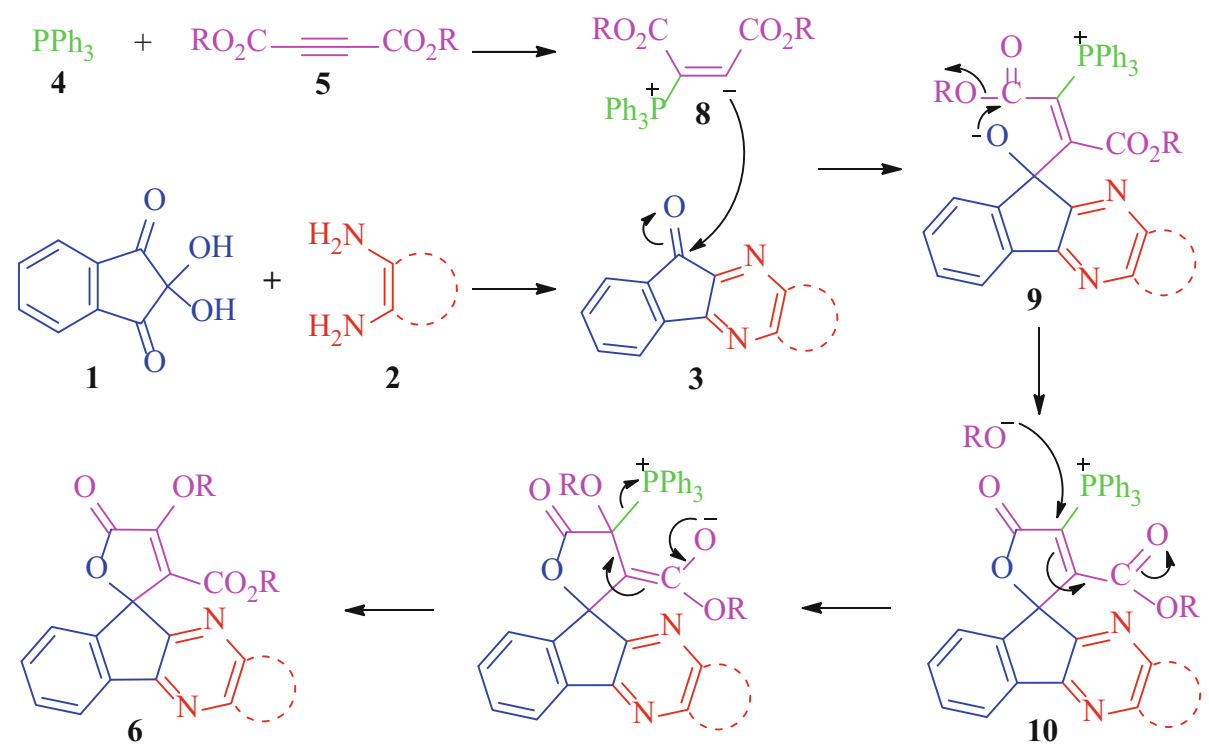

Scheme 3. Plausible mechanism for the synthesis of spirofuran-indenoquinoxaline derivatives.

\section{Conclusions}

In summary, we demonstrated an efficient one-pot domino three-component approach for the synthesis of novel spirofuran-indenoquinoxaline derivatives via the reaction between ninhydrin, various aromatic 1,2diamines and dialkyl ethynedicarboxylates in the presence of triphenylphosphine as catalyst in $\mathrm{CH}_{2} \mathrm{Cl}_{2}$ at ambient temperature. This domino strategy produces biologically useful heterocycles with the formation of $\mathrm{C}-\mathrm{C}, \mathrm{C}=\mathrm{N}, \mathrm{C}-\mathrm{O}$ bonds and two new rings in a single operation. The present procedure has the advantage that, not only is the reaction was performed under mild and neutral conditions, but also the substances can be mixed without any activation or modification. The method also offers several advantages such as good functional group tolerance, high atom economy, cost-effectiveness, good to excellent yields and easy work-up; i.e., the products can be isolated without chromatography.

\section{Supplementary Information (SI)}

IR, ${ }^{1} \mathrm{H},{ }^{13} \mathrm{C}$ NMR and Mass spectra and the table of elemental analyses for all the new compounds and the experimental details are available at www.ias.ac.in/chemsci.

\section{Acknowledgements}

We gratefully acknowledge financial support from the Research Council of the University of Sistan and Baluchestan and Young Researchers and Elite Club, Yazd Branch, Islamic Azad University, Yazd, Iran.

\section{References}

1. Dömling A 2006 Recent developments in isocyanide based multicomponent reactions in applied chemistry Chem. Rev. 10617

2. Yadav P, Kumar B, Gautam H K and Sharma S K 2017 Synthesis and antibacterial activity screening of quaternary ammonium derivatives of triazolyl pyranochromenones J. Chem. Sci. 129211

3. Ostrowska K, Grzeszczuk D, Maciejewska D, Młynarczuk-Biały I, Czajkowska A, Sztokfisz A, Dobrzycki $€$ and Kruszewska H 2016 Synthesis and biological screening of a new series of 5-[4-(4-aryl-1piperazinyl)butoxy]coumarins Monatsh. Chem. Chem. Mon. 1471615

4. Schreiber S L 2000 Target-oriented and diversityoriented organic synthesis in drug discovery Science $\mathbf{2 8 7}$ 1964

5. Udayakumar V, Gowsika J and Pandurangan A 2017 A novel synthesis and preliminary in vitro cytotoxic evaluation of dihydropyrimidine-2,4 $(1 \mathrm{H}, 3 \mathrm{H})$-dione derivatives J. Chem. Sci. 129249

6. Deshmukh S, Dingore K, Gaikwad V and Jachak M 2016 An efficient synthesis of pyrazolo [1,5-a] pyrimidines and evaluation of their antimicrobial activity $J$. Chem. Sci. 1281459

7. Tietze L F, Brasche G and Gericke K 2006 In Domino Reactions in Organic Synthesis (Weinheim: Wiley$\mathrm{VCH})$

8. Ivanov A S 2008 Meldrum's acid and related compounds in the synthesis of natural products and analogs Chem. Soc. Rev. 37789

9. Nikoofar K, Khademi Z and Haghighi M 2016 A Novel Green Catalyst for the One-step Cascade Condensation of Arylamines, Acetone and Isatins in Water J. Chem. Sci. 1281805

10. Tietze L F 1996 Domino reactions in organic synthesis Chem. Rev. 96115 
11. Tietze L F and Haunert F 2000 In Stimulating Concepts in Chemistry Votle F, Stoddart J F and Shibasaki M (Eds.) (Weinheim: Wiley-VCH) p. 39

12. Enders D, Huttl M R M, Grondal C and Raabe G 2006 Control of four stereocentres in a triple cascade organocatalytic reaction Nature 441861

13. Rios R 2012 Enantioselective methodologies for the synthesis of spiro compounds Chem. Soc. Rev. 411060

14. Jin T, Himuro M and Yamamoto Y 2009 Triflic acid catalyzed synthesis of spirocycles via acetylene cations Angew. Chem. Int. Ed. 485893

15. Hasaninejad A and Firoozi S 2013 One-pot, sequential four-component synthesis of benzo[c]pyrano[3,2a]phenazine, bis-benzo[c]pyrano[3,2-a]phenazine and oxospiro benzo[c]pyrano[3,2-a]phenazine derivatives using 1,4-diazabicyclo[2.2.2] octane (DABCO) as an efficient and reusable solid base catalyst Mol. Divers. 17499

16. Mane M M and Pore D M 2016 Sulfamic acid as energy efficient catalyst for synthesis of flurophores, 1$\mathrm{H}$-spiro[isoindoline-1,2' -quinazoline]-3, 4' $\left(3^{\prime} \mathrm{H}\right)$-diones J. Chem. Sci. 128657

17. Hasaninejad A, Firoozi S and Mandegani F 2013 An efficient synthesis of novel spiro [benzo[c]pyrano[3,2a]phenazines] via domino multi-component reactions using 1-proline as a bifunctional organocatalyst Tetrahedron Lett. 542791

18. Tanaka N, Kashiwada Y, Kim S Y, Hashida W, Sekiya M, Ikeshiro Y and Takaishi Y J 2009 Acylphloroglucinol, biyouyanagiol, biyouyanagin B, and related spirolactones from Hypericum chinense Nat. Prod. 721447

19. Pore D M, Patil P B, Gaikwad D S, Hegade P G, Patil J D and Undale K A 2013 Green access to novel spiro pyranopyrazole derivatives Tetrahedron Lett. 545876

20. Maghsoodlou M T, Habibi-Khorassani S M, Moradi A, Hazeri N, Davodi A and Sajadikhah S S 2011 One-pot three-component synthesis of functionalized spirolactones by means of reaction between aromatic ketones, dimethyl acetylenedicarboxylate, and $\mathrm{N}$-heterocycles Tetrahedron 678492

21. Shoker T A, Ghattass K I, Fettinger J C, Kurth M J and Haddadin M J 2012 Unusual Friedlander Reactions: A Route to Novel Quinoxaline-Based Heterocycles Org. Lett. 143704

22. Zohreh N and Alizadeh A 2013 Uncatalyzed One-Pot Synthesis of Highly Substituted Pyridazines and Pyrazoline-Spirooxindoles via Domino SN/Condensation/Aza-ene Addition Cyclization Reaction Sequence ACS Comb. Sci. 15278

23. Chen H and Shi D 2010 Efficient one-pot synthesis of novel spirooxindole derivatives via three-component reaction in aqueous medium J. Comb. Chem. 12571

24. Adib M, Sheikhi E, Kavoosi A and Bijanzadeh H R 2010 Synthesis of 2-(alkylamino)-5-alkyl[(2-oxo-2Hchromen-3-yl)carbonyl]amino-3,4-furandicarboxylates using a multi-component reaction in water Tetrahedron 669263

25. Peterson E M, Xu K, Holland K D, McKeon A C, Rothman S M, Ferrendelli J A and Covey D F 1994 Alpha-spirocyclopentyl-and alpha-spirocyclopropylgamma-butyrolactones: Conformationally constrained derivatives of anticonvulsant and convulsant alpha, alpha-disubstituted gamma-butyrolactones J. Med. Chem. 37275

26. Kupchan S M, Dessertine A L, Blaylock B T and Bryan R F 1974 Isolation and structural elucidation of allamandin, and antileukemic iridoid lactone from Allamanda cathartica J. Org. Chem. 392477

27. Trost B M, Balkovec J M and Mao M K -T 1983 A biomimetic approach to plumericin J. Am. Chem. Soc. 1056755

28. Indalkar K S, Khatri C K and Chaturbhuj G U 2017 Rapid, efficient and eco-friendly procedure for the synthesis of quinoxalines under solvent-free conditions using sulfated polyborate as a recyclable catalyst $J$. Chem. Sci. 129141

29. Seitz L E, Suling W J and Reynolds R C 2002 Synthesis and antimycobacterial activity of pyrazine and quinoxaline derivatives J. Med. Chem. 455604

30. Badran M M, Moneer A A, Refaat H M and El-Malah A A 2007 Synthesis and antimicrobial activity of novel quinoxaline derivatives J. Chin. Chem. Soc. 54469

31. Aguirre G, Cerecetto H, Di Maio R, Gonzales M, Alfaro M E M A, Jaso A, Zarranz B, Ortega M A, Aldana I and Monge-Vega A 2004 Quinoxaline N,N'-dioxide derivatives and related compounds as growth inhibitors of Trypanosoma cruzi. Structure-activity relationships Bioorg. Med. Chem. Lett. 143835

32. Sarges R, Howard H R, Browne R G, Lebel L A, Seymour P A and Koe B K 1990 4-Amino[1,2,4]triazolo[4,3a]quinoxalines. A novel class of potent adenosine receptor antagonists and potential rapid-onset antidepressants J. Med. Chem. 332240

33. Hazeldine S T, Polin L, Kushner J, White K, Bouregeois N M, Crantz B, Palomino E, Corbett T H and Horwitz J P 2002 II. Synthesis and biological evaluation of some bioisosteres and congeners of the antitumor agent, 2-4[(7-chloro-2-quinoxalinyl) oxy]phenoxy propionic acid (XK469) J. Med. Chem. 453130

34. Dastoorani P, Maghsoodlou M T, Khalilzadeh M A and Sarina E 2016 Synthesis of new dibenzofuran derivatives via Diels-Alder reaction of euparin with activated acetylenic esters Tetrahedron Lett. 57314

35. Maghsoodlou M T, Habibi-Khorassani S M, Heidari R, Rostami Charati F, Hazeri N, Lashkari M, Marandi G, Sobolev A and Makha M 2009 Highly stereoselective construction of functionalized cyclopropanes from the reaction between acetylenic esters and $\mathrm{C}-\mathrm{H}$ acids in the presence of triphenylarsine Tetrahedron Lett. 50 4439

36. Rostami Charati F, Maghsoodlou M T, HabibiKhorassani S M and Makha M 2008 Highly stereoselective construction of functionalized cyclopropanes from the reaction between acetylenic esters and $\mathrm{C}-\mathrm{H}$ acids in the presence of triphenylarsine Tetrahedron Lett. 49343

37. Doostmohammadi R, Maghsoodlou M T, Hazeri N and Habibi-Khorassani S M 2013 Acetic acid as an efficient catalyst for the one-pot preparation of 3,4,5-substituted furan-2(5H)-ones Res. Chem. Intermed. 394061

38. Doostmohammadi R, Maghsoodlou M T, Hazeri N and Habibi-Khorassani S M 2013 An efficient one-pot multi-component synthesis of 3,4,5-substituted furan$2(5 \mathrm{H})$-ones catalyzed by tetra-n-butylammonium bisulfate Chin. Chem. Lett. 24901 
39. Sajadikhah S S, Maghsoodlou M T and Hazeri N 2014 A simple and efficient approach to one-pot synthesis of mono-and bis-N-aryl-3-aminodihydropyrrol-2-one4-carboxylates catalyzed by $\mathrm{InCl}_{3}$ Chin. Chem. Lett. 25 58

40. Hudson H R 1990 In The Chemistry of Organophosphorus Compounds: Primary, Secondary, and Tertiary Phosphines and Heterocyclic Organophosphorus (III) Compounds (UK: Wiley) Vol. 1 pp. 386-472

41. (a) Engel R 1988 In Synthesis of Carbon-Phosphorus Bonds (Boca Raton, FL: CRC Press); (b) Cherkasov R A and Pudovik M A 1994 Heterophosphacyclanes in Organic Synthesis Russ. Chem. Rev. 631019

42. Ziyaadini M, Maghsoodlou M T, Hazeri N and HabibiKhorassani S M 2012 Novel synthesis of stable 1,5diionic organophosphorus compounds from the reaction between triphenylphosphine and acetylenedicarboxylic acid in the presence of $\mathrm{N}-\mathrm{H}$ heterocyclic compounds Monatsh. Chem. Chem. Mon. 1431681

43. Yavari I, Alizadeh A and Anary-Abbasinejad M 2003 Efficient synthesis of functionalized 2,5-dihydro-1,2oxaphospholes Tetrahedron Lett. 442877
44. Pearson B D, Mitsch R A and Cromwell N H 1962 Indenoquinolines. III. Derivatives of $11 \mathrm{H}$-Indeno[1,2b]quinoxaline and Related Indenoquinolines J. Org. Chem. 271674

45. Han Y, Guo L Y and Yan C G 2015 Triphenylphosphine catalyzed domino reaction of dialkyl acetylenedicarboxylate with 3-aryl-2-benzoylcyclopropane-1, 1dicarbonitrile Heterocycl. Commun. 21329

46. Asghari S and Khabbazi Habibi A 2012 Synthesis of Halogenated $\alpha, \beta$-Unsaturated $\gamma$-Butyrolactone Derivatives by Triphenylphosphine-Catalyzed Cyclization of $\alpha$-Halogeno Ketones with Dialkyl Acetylenedicarboxylates (=Dialkyl But-2-ynedioates) Helv. Chim. Acta 95 810

47. Anary-Abbasinejad M, Hassanabadi A and Gavarti M A 2012 Efficient One-Pot Synthesis of Alkyl 2-(Bromomethyl)-2-(4-aryl)-4-alkoxy-5-oxo2,5-dihydrofuran-3-carboxylate Synth. Commun. 42 1426 